\title{
Are Future Professionals Willing to Implement Service Robots? Attitudes of Hospitality and Tourism Students towards Service Robotization
}

\author{
Milan Ivkov ${ }^{1}$, Ivana Blešić ${ }^{1,2, * \mathbb{C}}$, Branislav Dudić ${ }^{3,4, * \mathbb{C}}$, Gabriela Pajtinková Bartáková ${ }^{3}$ and \\ Zdenka Dudić ${ }^{4}$ (D) \\ 1 Department of Geography, Tourism and Hotel Management, Faculty of Sciences, University of Novi Sad, \\ 21000 Novi Sad, Serbia; milan.ivkov@dgt.uns.ac.rs \\ 2 Institute of Sports, Tourism and Service, South Ural State University, 454080 Chelyabinsk, Russia \\ 3 Faculty of Management, Comenius University in Bratislava, 82005 Bratislava, Slovakia; \\ gabriela.bartakova@fm.uniba.sk \\ 4 Faculty of Economics and Engineering Management, University Business Academy, 21000 Novi Sad, Serbia; \\ zdenkadudic79@gmail.com \\ * Correspondence: ivana.blesic@dgt.uns.ac.rs (I.B.); branislav.dudic@fm.uniba.sk (B.D.)
}

Received: 13 August 2020; Accepted: 1 September 2020; Published: 4 September 2020

\begin{abstract}
This paper aims to examine attitudes of hospitality and tourism students, as future professionals, towards willingness to implement service robots. The study proposes a new theoretical conceptual model that includes new constructs and items, differentiating it from the others. The model was formed based on the extensive literature review and the interview with an eight-member focus group (hotel managers and academic researchers). Data collection was performed in two stages, pilot research based on 82 respondents and the main study, with the final number of respondents being 236 . The initial results of the exploratory factor analysis were further tested using the confirmatory factor analysis. After the exclusion of several items due to low factor loadings and in order to improve model validity, analyses further suggested a nine-dimensional solution with 45 items. The study findings reveal a positive relationship between seven constructs and students' willingness to implement service robots, with the expected business outcome being the most influencing one. On the other hand, positive relation was not found for empathy and social influence constructs. Theoretical contributions and practical implications are discussed in the paper. In conclusion, study limitations and future research suggestions are provided.
\end{abstract}

Keywords: service robots; willingness to implement service robots; students; hospitality; tourism

\section{Introduction}

The presence of robots in today's hospitality and tourism companies has increased dramatically. An increasing usage of robots in service companies has been affecting the process of service delivery, shaping customer needs and taking their experiences to a whole new level. By having robots present in personal and public spaces [1-4], numerous hospitality and tourism stakeholders use them to enhance their operations, performance and service personalization. This sophisticated technology has become the tool to deliver consistent product quality [5].

For instance, in 2016 Hilton Worldwide Holdings Inc. introduced the world's first hotel concierge robot powered by artificial intelligence, named Connie, after the company founder Conrad Hilton. Connie can offer customers personalized attention, answer their questions and give required recommendations in real-time [6,7]. Furthermore, it was introduced with three main 
reasons: (1) decrease in waiting time, (2) added efficiency in hotel operations and (3) getting the Wow effect with an innovative and unique service [8].

Similarly, other hotel companies such as Marriott and Holiday Inn have incorporated robots into their service operations. Relay and Wally are basically a room service staff $[9,10]$. Starwood hotel company also has a robotic butler (Botlr) named A.L.O. after the Aloft hotel, which can deliver room service, while the Yotel hotel in New York provides guests with a luggage handling robot [8]. Examples of robot technology adoption in tourism and hospitality are numerous, they can be implemented at airports, cruise ships [11] or in restaurants, travel agencies, tourist centers, car rental companies, meetings and events, theme parks or museums and galleries [5]. However, one of the examples of complete automation is the Henn na Hotel in Japan, which is completely operated by robots, without the presence of any human employee [12].

The demand for robots in a service environment is on the rise and recent global research by [13] shows that consumers believe robots can enhance their experience but it also reveals a certain worry regarding unemployment of human staff. Moreover, [3] points out the fact that hospitality relies on the interpersonal interaction between customers and employees to create recognizable value, and that service robots represent a certain challenge to the traditional understanding of hospitality.

Previous studies addressed various issues related to robotics in hospitality and tourism, e.g., service delivery and encounters [14-17], service innovation [18], customer experience [19,20], customers interaction with robots [2,21-23], effects on customer perception and attitudes [3,4,21,24], customer trust [25] and managerial operations $[4,26]$.

The term service robot used in this study is grounded on an explanation given by [27] and refers to an autonomous or semiautonomous device that interacts and communicates with people by following behavioral patterns expected from human employees.

Although topics related to robotics in the service sector have drawn scholars' attention [28], primarily with the focus on consumers and their willingness to use robots, the academic research that examines managers' or employees' attitudes towards the implementation of the service robots in hospitality and tourism companies still remains scarce (see $[29,30])$. Therefore, this paper aims to bring to light attitudes of hospitality and tourism students as future professionals in this area. As these young people belong to generation $Z$, they are quite familiar with various examples of adoption of innovative technology. Hence, in this study, the main objective is to test students' willingness to implement service robots in hospitality and tourism companies, given the chance. Additionally, proposed hypotheses will help to reveal which factors have the largest influence on their willingness to do so.

\section{Theoretical Background}

\subsection{Willingness to Use and Implement Robots}

Over the last decades, numerous studies examined consumers' willingness and intention to accept the use of information technology, robots and devices with artificial intelligence [3,22,24,31-35]. Moreover, willingness is described as a key factor in determination of the consumers' behavior [36] and it was recognized as such a few decades ago [37].

The vast majority of published studies dominantly rely on existing technology acceptance models and concepts, e.g., technology acceptance model (TAM) proposed by [38], unified theory of acceptance and use of technology (UTAUT) [32] and its revised form UTAUT2 [33]. As noted by [24], those models do not focus on innovative artificial intelligence technology acceptance and their use in such constructs is limited. Thus, most recent studies propose more adequate models such as the artificially intelligent device use acceptance (AIDUA) [24] or service robot integration willingness scale (SRIW) [3], or use a modified model for qualitative research in hospitality [22]. Additionally, some authors [28] recognized the importance of consumers' behavior related to robots and implemented different theories and models into their research. 
For the purpose of this study, this construct was renamed to 'Willingness to implement service robots' and refers to students' general tendency to implement them at work, given the chance.

\subsection{Expected Business Outcome (EBO)}

The expected business outcome is one of the main drivers in a decision-making process within hospitality and tourism industries $[39,40]$. They are basically the set of goals a company uses to measure achievements of various processes. Han, Hsu and Sheu [41] argue that decision makers evaluate potential outcomes when thinking whether to make some actions or not. These outcomes are related to all areas of business such as organization, operations and processes, marketing, service/product development, performance, finance, innovations, human resources, service quality, guest satisfaction, etc. Hence, authors consider this construct as being vital for decision makers/managers (or future professionals in this study) and integrated it within the proposed conceptual model (Figure 1). Moreover, the first hypothesis proposes that:

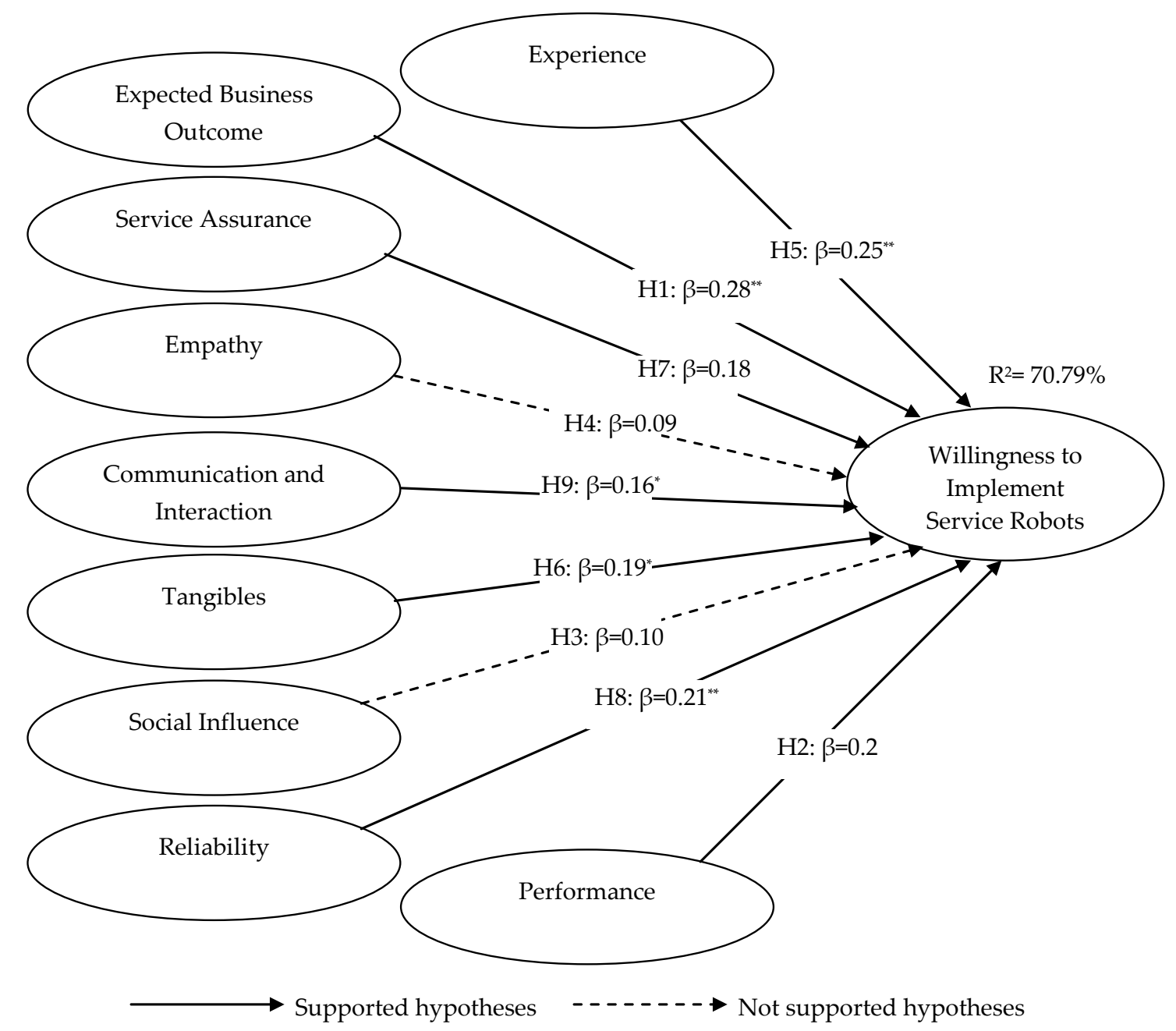

Figure 1. Proposed conceptual model. ${ }^{*} p<0.05$; and ${ }^{* *} p<0.01$.

Hypothesis 1 (H1). The expected business outcome is positively related to willingness to implement service robots.

\subsection{Performance (PER)}

Performance as a construct in this study refers to students' perception of robots' performance in terms of accuracy, service delivery speed and consistency. Robot performance in hospitality and tourism settings can be described as the accomplishment of a task defined by the set of standards of 
a company. Hence, in-depth technology assessment can further improve robots' performance [42]. Such perceived benefits positively affect the intention to use new technology [35]. A similar construct named performance expectancy was proposed in the AIDUA model by [24]. Additionally, some of the items within this construct appear across differently named factors in other studies [22,43]. For detailed description of used items in this study, refer to Table 1. Thus, the second hypothesis suggests that:

Hypothesis 2 (H2). Performance is positively related to willingness to implement service robots.

\subsection{Social Influence (SI)}

Social influence is usually defined as the process by which an individual's attitudes or actions are affected by others. It is also described as a degree to which a person perceives important beliefs of others regarding the adoption of new technology [32] or to the degree that a group believes that innovative technology devices (e.g., robots) are in line with existing social norms [24], which can be crucial for the individual's behavioral patterns [44], especially when influence comes from friends and family [45]. As the application of robotic devices is still new to hospitality and tourism stakeholders, their decisions on whether to implement this technology and to what extent are likely to be affected by society. This is more likely to happen if decision makers are females, as they find social influence, related to the use of innovative technology, more important than men [46]. Thus, the next hypothesis (H3) proposes that:

Hypothesis 3 (H3). Social influence is positively related to willingness to implement service robots.

\subsection{Empathy (EMP)}

Service environments in the hospitality and tourism sector inevitably include employee-customer interactions. Those interactions are vital for the completion of the service delivery process [47]. If empathy as the employee's perception and understanding of customer feelings during a service delivery [48] is present, it is likely that the service outcome will be pleasing [49]. Additionally, expressed empathy towards customers is crucial for the perception of service experience and overall service quality [50]. Hence, the service received from robots must appeal to consumers [22]. Hence, the following hypothesis is suggested:

Hypothesis 4 (H4). Empathy is positively related to willingness to implement service robots.

\subsection{Experience (EXP)}

The perception of fun, pleasure and enjoyment related to the use of innovative technology, is often linked to hedonic motivation in existing literature [24,33,35]. However, some studies [43] associate them with the experience construct. Numerous studies argue that such positive emotions derived from the use of innovative technology, e.g., service robots, represent a key motive and predictor of technology adoption and use [32,33,43,51-55]. People who seek novelty and new experiences are likely to use robots in service settings, which leads to another hypothesis:

Hypothesis 5 (H5). Customer experience is positively related to willingness to implement service robots.

\subsection{Tangibles (TG)}

Tangibles could be described as an aspect of service that can be seen and felt. It is related to physical environment, equipment, staff and communications materials [56]. As service robots now can serve customers and talk to them, they are considered personnel. Furthermore, in such settings, tangibility is applicable as the service quality aspect is used to improve customer satisfaction. The results of a study conducted in a robot café indicated a high score of service tangibility [57]. On the contrary, a recent study on the robots' influence on service quality showed negative differences between customer 
expectations and the robots' performance related to tangible aspects [58]. In light of the current global health concern, this construct was extended accordingly. Although recent studies show quite the opposite findings regarding the perception of tangibles, the proposed hypothesis states that:

Hypothesis 6 (H6). Tangibles are positively related to willingness to implement service robots.

\subsection{Service Assurance (SAR)}

Service assurance, in the context of robotization in hospitality and tourism, can be defined as the complex process of establishing, maintaining and enhancing the quality of service provided by robots to customers. It actually ensures that provided services correspond to company standards and service quality levels. Keeping in mind the definition of service assurance provided by [50], and in the context of this study, it also refers to service robots' ability to create the feeling of trust and confidence among customers. Unfortunately, this is a challenging task for robots and they can offer poor service due to malfunction or unexpected issues while performing. In such situations, customers evaluate their knowledge and the ability to inspire trust as being very low [57]. Nevertheless, the proposed hypothesis is as follows:

Hypothesis 7 (H7). Service assurance is positively related to willingness to implement service robots.

\subsection{Reliability (REL)}

Reliability of robots in the service environment can be defined as their ability to perform the service that a company promised dependably and accurately. The study conducted in a robot café [57] reported customers' high evaluation of the reliability aspect. While some papers [59] verified reliability as one of the three trusting dimension, more recent studies [60], presented the service reliability aspect within the performance construct, being just one of its subdimensions. In the same study [60], authors noted the importance of the accuracy during service delivery and relevant information to customers, as this improves their perception of reliability. Since provision of the promised service, i.e., the exact details that customers ordered, plays a significant role for both customers and service providers, another hypothesis is suggested:

Hypothesis $\mathbf{8}$ (H8). Reliability is positively related to willingness to implement service robots.

\subsection{Communication and Interaction (CAI)}

Communication, as a specific form of interaction, is the process of sharing verbal and non-verbal information between engaged parties, in this case, humans and robots. As stated by [50], it is also a continuation of the service assurance promises. While other studies [22] focus on communication, i.e., information sharing and interaction with robots as two independent constructs, in this study, these constructs are merged into the communication and interaction construct. Although [22] named one of the constructs personal engagement, the proposed items are related to interaction, same as in this study. Even though hospitality customers may have problems with new technology adoption due to an unfamiliar communication platform [61], the human-robot encounter involves interactions with the purpose of meeting customers' needs [22]. Therefore, the proposed hypothesis is that:

Hypothesis 9 (H9). Communication and interaction have a positive effect on willingness to implement service robots.

\section{Materials and Methods}

\subsection{Participants and Procedures}

Initially, literature on service robots, artificial intelligence, service quality and service delivery was reviewed. Items identified in previous studies were assembled to form the initial questionnaire 
(58 items). Subsequently, authors interviewed a group of eight experts constituted by academic researchers and hotel managers (focus group) to refine the selected constructs and items. Items identified at this stage were compiled to form the initial item pool (52 items).

Thirdly, the online survey was used in order to collect data from the students of University of Novi Sad, Department of Geography, Tourism and Hotel Management (Serbia). The online survey was distributed through existing Facebook groups that professors use to communicate to students. The students of three courses (tourism, hotel management and gastronomy) were included in the study in the ratio of $35.74 \%, 32.7 \%$ and $31.56 \%$ respectively. In order to additionally inform participants and obtain more reliable responses, the online questionnaire included photographs and web links to video examples of the application of service robots in the hospitality and tourism industry, and a short textual explanation of their use.

The pretest was carried out in January 2020 and the main study was conducted from March to June 2020. The first sample of 82 participants was used to ensure reliability and construct validity using EFA (exploratory factor analysis) with principal component analysis and Varimax rotation (SPSS 23.0). The second sample of 263 respondents was used to evaluate the latent structure using the confirmatory factor analysis (CFA) based on results from the EFA (Mplus 7.0).

\subsection{Survey Instrument}

The final questionnaire used in this study consisted of two parts. The first part was related to the respondents' profile (gender and course). The sample consisted of more females (59.3\%) and over 90\% of the students had not had a chance to use service robots or to work with them. The second part of the questionnaire consisted of 46 items measuring the students' willingness to implement service robots at work, given the chance. Most of the items were adopted from previous scales (Table 1). All the statements were estimated on the 5-point Likert scale (1—-strongly disagree and 5-strongly agree).

Table 1. Constructs and items.

\begin{tabular}{|c|c|c|}
\hline Construct & Item & Source \\
\hline \multirow{6}{*}{ Experience (EXP) } & Robot service is an innovative idea. & [62] \\
\hline & It is entertaining being in the robot environment. & ** new \\
\hline & Watching robots performing their tasks is interesting. & ** new \\
\hline & Being served by robots is a memorable experience. & [43] \\
\hline & Robots are useful in enhancing experiences in a service environment. & [22] \\
\hline & The use of robot technology makes a service experience more enjoyable. & [22] \\
\hline \multirow{5}{*}{$\begin{array}{l}\text { Expected Business Outcome } \\
\qquad(\mathrm{EBO})\end{array}$} & The use of robots improves company revenue. & {$[62]$} \\
\hline & The use of robots improves company competitiveness. & [62] \\
\hline & The use of robots improves efficiency of service processes. & {$[62]$} \\
\hline & The use of robots extends potential markets. & [62] \\
\hline & The use of robots reduces costs. & {$[62]$} \\
\hline \multirow{5}{*}{ Service Assurance (SAR) } & Customer services are safe with robots in a service environment. & [22] \\
\hline & $\begin{array}{l}\text { Robots in a service environment are programmed to cater to specific } \\
\text { customers' needs. }\end{array}$ & [22] \\
\hline & Actions of the robots are giving a feeling of trust. & [22] \\
\hline & The robots have sufficient knowledge about services. & [22] \\
\hline & $\begin{array}{l}\text { Robots in a service environment are friendlier compared to } \\
\text { human employees. }\end{array}$ & ** new \\
\hline
\end{tabular}


Table 1. Cont.

\begin{tabular}{|c|c|c|}
\hline Construct & Item & Source \\
\hline \multirow{4}{*}{ Empathy (EMP) } & $\begin{array}{l}\begin{array}{l}\text { Robots in a service environment usually understand the specific needs } \\
\text { of the customers. }\end{array}\end{array}$ & [22] \\
\hline & $\begin{array}{l}\text { Robots in a service environment are available whenever it is convenient } \\
\text { for customers. }\end{array}$ & [22] \\
\hline & * Robots cannot understand a customer's emotions. & [43] \\
\hline & Robots pay individual attention to the customer. & [22] \\
\hline \multirow{6}{*}{$\begin{array}{l}\text { Communication and } \\
\text { Interaction (CAI) }\end{array}$} & Sharing information with robots in a service environment is easy. & [22] \\
\hline & $\begin{array}{l}\text { Information shared by robots in a service environment is } \\
\text { easily understandable. }\end{array}$ & [22] \\
\hline & Information provided by robots is more consistent. & [3] \\
\hline & It is comfortable interacting with robots in a service environment. & [22] \\
\hline & $\begin{array}{l}\text { It is more comfortable interacting with robots than humans in a service } \\
\text { environment. }\end{array}$ & [22] \\
\hline & It is easier to interact with robots than humans in a service environment. & [22] \\
\hline \multirow{5}{*}{ Tangibles (TG) } & $\begin{array}{c}\text { Robots in a service environment are part of the visually } \\
\text { appealing setting. }\end{array}$ & [22] \\
\hline & $\begin{array}{l}\text { Robots in a service environment are offering the view of a } \\
\text { modern-looking company. }\end{array}$ & [22] \\
\hline & $\begin{array}{l}\text { Robots in a service environment visually look better than some } \\
\text { human employees. }\end{array}$ & [22] \\
\hline & Robots have better hygienic practice. & ${ }^{* *}$ new \\
\hline & Robots cannot transmit diseases to humans. & ${ }^{* *}$ new \\
\hline \multirow{6}{*}{ Social Influence (SI) } & $\begin{array}{l}\text { Using robots reflects a status symbol in my social networks } \\
\text { (e.g., friends, family and coworkers). }\end{array}$ & [24] \\
\hline & People who influence my behavior would want me to utilize robots. & [24] \\
\hline & $\begin{array}{c}\text { People in my social networks who would utilize robots have more } \\
\text { prestige than those who do not. }\end{array}$ & [24] \\
\hline & People whose opinions I value would prefer that I utilize robots. & [24] \\
\hline & People who are important to me would encourage me to utilize robots. & [24] \\
\hline & $\begin{array}{l}\text { People in my social networks who would utilize robots have a } \\
\text { high profile. }\end{array}$ & [24] \\
\hline \multirow{4}{*}{ Reliability (REL) } & Robots provide properly what customers ordered. & [22] \\
\hline & Robots can carry out services properly. & [22] \\
\hline & * Robots can malfunction during service. & [43] \\
\hline & $\begin{array}{c}\text { * Robots cannot do special requests/they work only in a } \\
\text { programmed frame. }\end{array}$ & [43] \\
\hline \multirow{4}{*}{ Performance (PER) } & Robots are faster than human employees. & [43] \\
\hline & Robots are more accurate than humans. & [3] \\
\hline & Robots provide more consistent service than humans. & [3] \\
\hline & Robots in a service environment enable the service to be more seamless & [22] \\
\hline $\begin{array}{l}\text { Willingness to Implement } \\
\text { Service Robots (WISR) }\end{array}$ & Given the opportunity, I will implement service robots at work. & [3] \\
\hline
\end{tabular}

Note: ${ }^{*}$ reverse coding and ${ }^{* *}$ new proposed items based on the literature review and the interview with the focus group.

\section{Results}

The results of the exploratory factor analysis (EFA), which suggested a nine-factor solution, included 45 items and explained 79.53\% of the variance (Table 2). The item "Given the opportunity, I will implement service robots at work" $(M=3.12 ; S D=0.723)$ was used to measure the criterion variable "Willingness to implement service robots", which was further omitted from the EFA. The Kaiser-Meyer-Olkin (KMO) overall measure of sampling adequacy was 0.91, which was middling [63], and the Bartlett's test of sphericity [64] was significant $(p=0.000)$. Factor loadings of all 
constructs were greater than 0.3 with $t$-values exceeding 1.96 , thus supporting convergent validity [65]. Seven items were deleted due to low factor loadings. Cronbach's $\alpha$ values for each factor were greater than 0.7 . The results showed that the alpha coefficients of the nine factors ranged from 0.820 to 0.897 . This confirms that the scales of the obtained questionnaire have considerable reliability [66].

Table 2. Exploratory and confirmatory factor analysis results.

\begin{tabular}{|c|c|c|c|c|c|c|}
\hline Constructs & Variables & $\begin{array}{c}\text { Factor } \\
\text { Loadings }\end{array}$ & $\begin{array}{c}\text { Cronbach's } \\
\alpha\end{array}$ & $\begin{array}{l}\text { Standardized } \\
\text { Loadings }\end{array}$ & CR & AVE \\
\hline \multirow{6}{*}{$\begin{array}{c}\text { Experience (EXP) } \\
\text { (Hypothesis 5) }\end{array}$} & EXP 1 & 0.923 & \multirow[t]{6}{*}{0.890} & 0.901 & \multirow[t]{6}{*}{0.912} & \multirow[t]{6}{*}{0.620} \\
\hline & EXP 2 & 0.879 & & 0.856 & & \\
\hline & EXP 3 & 0.865 & & 0.812 & & \\
\hline & EXP 4 & 0.832 & & 0.815 & & \\
\hline & EXP 5 & 0.827 & & 0.800 & & \\
\hline & EXP 6 & 0.790 & & 0.823 & & \\
\hline \multirow{5}{*}{$\begin{array}{c}\text { Expected Business } \\
\text { Outcome (EBO) } \\
\text { (Hypothesis 1) }\end{array}$} & EBO1 & 0.895 & \multirow[t]{5}{*}{0.867} & 0.811 & \multirow[t]{5}{*}{0.952} & \multirow[t]{5}{*}{0.635} \\
\hline & EBO2 & 0.870 & & 0.789 & & \\
\hline & EBO3 & 0.869 & & 0.770 & & \\
\hline & EBO4 & 0.854 & & 0.816 & & \\
\hline & EBO5 & 0.812 & & 0.798 & & \\
\hline \multirow{4}{*}{$\begin{array}{c}\text { Service Assurance } \\
\text { (SAR) } \\
\text { (Hypothesis 7) }\end{array}$} & SAR1 & 0.951 & \multirow[t]{4}{*}{0.852} & 0.847 & \multirow[t]{4}{*}{0.918} & \multirow[t]{4}{*}{0.814} \\
\hline & SAR2 & 0.897 & & 0.851 & & \\
\hline & SAR3 & 0.844 & & 0.796 & & \\
\hline & SAR4 & 0.780 & & 0.758 & & \\
\hline \multirow{4}{*}{$\begin{array}{c}\text { Empathy (EMP) } \\
\text { (Hypothesis 4) }\end{array}$} & EMP1 & 0.856 & \multirow[t]{4}{*}{0.817} & 0.841 & \multirow[t]{4}{*}{0.905} & \multirow[t]{4}{*}{0.790} \\
\hline & EMP2 & 0.832 & & 0.802 & & \\
\hline & EMP3 & 0.798 & & 0.745 & & \\
\hline & EMP4 & 0.756 & & 0.777 & & \\
\hline \multirow{6}{*}{$\begin{array}{l}\text { Communication and } \\
\text { Interaction (CAI) } \\
\text { (Hypothesis 9) }\end{array}$} & CAI1 & 0.902 & \multirow[t]{6}{*}{0.897} & 0.874 & \multirow[t]{6}{*}{0.913} & \multirow[t]{6}{*}{0.678} \\
\hline & CAI2 & 0.900 & & 0.912 & & \\
\hline & CAI3 & 0.858 & & 0.847 & & \\
\hline & CAI4 & 0.852 & & 0.843 & & \\
\hline & CAI5 & 0.795 & & 0.800 & & \\
\hline & CAI6 & 0.752 & & 0.769 & & \\
\hline Tangibles (TG) & TG1 & 0.888 & \multirow[t]{6}{*}{0.847} & 0.847 & \multirow[t]{6}{*}{0.915} & 0.801 \\
\hline \multirow[t]{5}{*}{ (Hypothesis 6) } & TG2 & 0.861 & & 0.831 & & \\
\hline & TG3 & 0.832 & & 0.785 & & \\
\hline & TG4 & 0.814 & & 0.789 & & \\
\hline & TG5 & 0.801 & & 0.777 & & \\
\hline & TG6 & 0.785 & & 0.760 & & \\
\hline Social Influence (SI) & SI1 & 0.882 & 0.837 & 0.848 & 0.901 & 0.654 \\
\hline (Hypothesis 3) & SI2 & 0.865 & & 0.862 & & \\
\hline & SI3 & 0.854 & & 0.781 & & \\
\hline & SI 4 & 0.809 & & 0.765 & & \\
\hline & SI5 & 0.800 & & 0.739 & & \\
\hline & SI6 & 0.785 & & 0.796 & & \\
\hline Reliability (REL) & REL1 & 0.832 & 0.820 & 0.821 & 0.893 & 0.612 \\
\hline (Hypothesis 8) & REL2 & 0.819 & & 0.796 & & \\
\hline & REL3 & 0.807 & & 0.762 & & \\
\hline & REL4 & 0.802 & & 0.826 & & \\
\hline Performance (PER) & PER1 & 0.901 & 0.889 & 0.879 & 0.916 & 0.637 \\
\hline (Hypothesis 2) & PER2 & 0.898 & & 0.835 & & \\
\hline & PER3 & 0.880 & & 0.866 & & \\
\hline
\end{tabular}


Using MPlus 7.0 [67] with the second (main) sample $(n=263)$, the authors performed confirmatory factor analysis (CFA) to confirm the latent structure and establish the convergent validity, discriminant validity and reliability of all variables (Table 2). The final CFA results suggested adequate model fit: $\chi 2=790.600(\mathrm{df}=284, p<0.001), \mathrm{CFI}=0.952, \mathrm{TLI}=0.945, \mathrm{RMSEA}=0.051$ (95\% CI: 0.047-0.055) and $\mathrm{SRMR}=0.049$. The results indicate a good fit by exceeding the cut-off criteria [68-70].

The composite reliability scores for each factor ranged from 0.893 to 0.952 , exceeding the 0.70 cut-off [71]. Convergent validity was assessed by examining the significance of item-to-factor loadings and the average variance extracted (AVE) for each factor. All standardized factor loadings ranged from 0.739 to 0.912 and the values of AVE for each dimension ranged from 0.612 to 0.814 , which were greater than $0.50[72,73]$. Thus, the measurement model indicated considerable convergent validity.

The validity of the constructs was tested by comparing the squared correlations of the factors with the average variance extracted for each of the factors. As Table 3 shows, the average variance extracted for each factor was greater than its squared correlations with other factors, thus supporting discriminant validity $[72,73]$.

Table 3. Results of the discriminant validity analysis from CFA.

\begin{tabular}{cccccccccc}
\hline & EXP & EBO & SAR & EMP & CAI & TG & SI & REL & PER \\
\hline EXP & $\mathbf{0 . 6 2 0}$ & & & & & & & & \\
EBO & 0.421 & $\mathbf{0 . 6 3 5}$ & & & & & & & \\
SAR & 0.475 & 0.580 & $\mathbf{0 . 8 1 4}$ & & & & & & \\
EMP & 0.458 & 0.498 & 0.550 & $\mathbf{0 . 7 9 0}$ & & & & & \\
CAI & 0.370 & 0.423 & 0.463 & 0.623 & $\mathbf{0 . 6 7 8}$ & & & & \\
TG & 0.580 & 0.562 & 0.542 & 0.589 & 0.527 & $\mathbf{0 . 8 0 1}$ & & & \\
SI & 0.420 & 0.485 & 0.325 & 0.374 & 0.333 & 0.356 & $\mathbf{0 . 6 5 4}$ & & \\
REL & 0.357 & 0.601 & 0.523 & 0.536 & 0.466 & 0.412 & 0.318 & $\mathbf{0 . 6 1 2}$ & \\
PER & 0.425 & 0.523 & 0.477 & 0.489 & 0.374 & 0.423 & 0.478 & 0.311 & $\mathbf{0 . 6 3 7}$ \\
\hline
\end{tabular}

Note: the bold diagonal values are the variance shared between the constructs and their measures. Off diagonal elements are the squared correlations between constructs.

In the structural model (Figure 1) seven factors, except for empathy ( $\beta=0.09, p=0.091$ ) and social influence $(\beta=0.10, p=0.077)$, show significant effects on the respondents' willingness to implement service robots at work. Experience $(\beta=0.25, p=0.007)$, expected business outcome $(\beta=0.28, p=0.004)$, service assurance $(\beta=0.18, p=0.039)$, communication and interaction $(\beta=0.16, p=0.002)$, tangibles ( $\beta=0.19, p=0.002)$, reliability $(\beta=0.21, p=0.001)$ and performance $(\beta=0.26, p=0.005)$ had significant positive effects on the respondents' willingness to implement service robots. Thus, hypotheses $\mathrm{H} 1$, $\mathrm{H} 2$ and $\mathrm{H} 5-\mathrm{H} 9$ were supported while hypotheses $\mathrm{H} 3$ and $\mathrm{H} 4$ were rejected. The R-square value of willingness to implement service robots in this model stood at 70.79\% (Figure 1).

\section{Discussion and Conclusions}

As academic research on the managers' or future professionals' attitudes towards the implementation of service robots is scarce, the purpose of this article was to bring to attention the importance of attitudes of industry managers, i.e., decision makers, as the development and implementation of innovative ideas largely depend on them.

The results of the present study support the proposed nine construct model with a good fit $(\chi 2=790.600(\mathrm{df}=284, p<0.001), \mathrm{CFI}=0.952, \mathrm{TLI}=0.945, \mathrm{RMSEA}=0.051$ (95\% CI: $0.047-0.055)$ and SRMR $=0.049)$. The obtained R-square score $(70.79 \%)$ of the proposed model demonstrates that willingness to implement service robots in the hospitality and tourism industry is dominantly explained by the expected business outcome $(\mathrm{H} 1)$, followed by performance $(\mathrm{H} 2)$, experience $(\mathrm{H} 5)$, reliability (H8), tangibles (H6), service assurance (H7) and communication and interaction (H9), while empathy (H4) and social influence (H3) did not prove any significant influence. 
The study findings point out that students, as future professionals in the hospitality and tourism field, recognize the main aspects of successful business orientation. This is vital as hospitality services have been gaining larger importance [74]. Based on their evaluation of the items within the expected business outcome construct (e.g., cost reduction, efficiency and revenue improvement, increased market share, etc.), it can be noted that they already think as managers, and that this factor prevalently affects their willingness to implement service robots. In terms of accessing new markets, other authors also recognized new technologies as a key factor [75]. Similarly, other scholars also reported that managers (decision makers) mainly see robots as a tool to facilitate and increase service delivery and capacity [76], and to lower costs [30,77]. Furthermore, [77] notes that robots can save up to $50 \%$ of the costs in comparison with conventional hotel organization, and assume that one third of the sector jobs could be substituted with robots within the next two decades. Moreover, [29] agrees that service robots will be widely used in years to come but they emphasize that their deployment should remain in sectors with less robot-customer interaction.

Findings of this study reveal that performance is the second most influential factor related to willingness to implement service robots. It reflects the decision makers' desire to provide a fast, accurate and consistent service. In the context of hospitality, these findings are in line with other studies that presented performance as an essential component and determinant of the application and use of service robots, emphasizing their competitive advantages over humans and further indirect positive effects on other factors that influence willingness to use service robots [3,24]. It is optimistic to notice a clearly shaped perception among students regarding the most important business aspects, crucial in fighting severe competition. Hence, speed, accuracy, consistency and seamless service are the aspects that largely describe the students' willingness to implement service robots.

Based on the study of [33], it can be suggested that as people gain more and more experience, the attractiveness of the robotized service as a source of fun, pleasure and enjoyment and therefore the main factor for technology acceptance will slowly disappear. Thus, customer experience as a main motivation will lose its influence over time and people will use robots for other reasons, mainly because of their efficiency. In regard to the enhancement of customer experience, some authors [78] point out the importance of the promotion of natural dialogue between robots and humans. Importantly, as this study was conducted primarily among students, it is worth mentioning that younger people seek more innovativeness [79]. Therefore, it is not surprising that the experience aspect (e.g., desire to create the wow effect through enjoyment and a memorable experience) greatly (the third most influential factor) affects their willingness to implement service robots, as they would probably use them themselves. However, future professionals should keep in mind that this could be good for the initial business but efficiency of cost-effectiveness must not be forgotten.

Reliability and service assurance are two constructs derived from the SERQUAL model [50] and they relate to service quality aspects. The results of this study indicate their positive relation to the students' willingness to implement service robots, given the opportunity. Moreover, students strongly believe that robots can carry out services properly and that they have enough knowledge about services they provide. This is important as reliability proved to have a significant influence on the overall company performance [62]. In their study, [22] found a significant positive link between service assurance and perceived value of robots, which positively influences the intention to use robots further.

Being one of the main determinants of competitiveness and creation of desired guest experiences [76], the tangible aspect of a robotized service (e.g., robots' physical appearance, design, etc.) is used to enhance the overall service quality. The results of the study also confirm a positive relation between tangibles and the respondents' willingness to implement service robots (the fourth most influential factor). Comparably, a recent study regarding robots in the hospitality industry [22] found a positive effect of tangibles on the perceived value of robots that further influences the intention to use robots. Not only do visually appealing elements such as colors, smell, etc., play a significant role in customer perception of the delivered service, but in light of the new global virus outbreak, other robot characteristics have also come into focus. Thus, this study proposed two new items related to the 
robots' hygienic practice and their inability to get sick and therefore transmit disease to customers. These new items were highly evaluated by the students and one of the reasons for that is probably the period of data collection, i.e., media influence. Similarly, [80] stated that service companies have been using robots due to the COVID-19 pandemic in order to elevate hygienic and sanitary practices and maintain suggested social distance.

In line with the findings of [22], the results of the present study suggest a positive influence of communication, and human-robot interaction in general, on the willingness to implement service robots. As noted by [81] communication positively affects employee self-efficiency, rapport building with customers, user experience or competitiveness [82], while [83] and [84] agree that information sharing helps having the customer in focus, i.e., enhancing responsiveness to their needs. Hence, the main determinant of the successful implementation of service robots in the hospitality industry relies on the level of their autonomy and quality of the human-robot interaction [85]. Future decision makers should keep this in mind as recent studies show low quality of the human-robot interaction and the expectation of demanding (VIP) guests to see human employees [14], robots' inability to replace human employees during interaction [84], especially in upscale establishments that focus on the value of human-human interaction [4].

Ref. [86] states that social influence is vital only in the early stage of someone's experience with new technology, when the individual lacks the necessary knowledge to make their own decisions. With the gain of knowledge and more experience, the effect of social groups decreases [87]. As noted, the respondents in this research belong to generation $\mathrm{Z}$ and hence they are familiar with innovative technology. In other words, the concept of automatized and robotized services is not unknown to them. We believe that this is the reason why social influence is not a predictor of willingness to implement service robots. Comparably, $[3,35]$ also reported the absence or limited social influence on the willingness to use robots.

Some studies concluded that for a good service, a human-human interaction is required [88], especially in the hotel industry [89] where people may refuse to use this technology due to a lack of meaningful interaction [88]. Hospitality and tourism decision makers should keep in mind these findings of the application of robotic technology is a long-term assessment. On the other hand, hotel customers may be willing to use robots due to the new experience and service novelty [90]. Although positive emotions and empathy positively affects the willingness to accept the use of robots, i.e., intention to use them [22,35], the idea itself of robots being able to establish a significant relationship with customers seems to be hard to achieve [91] and it will take decades for robots to master such complex tasks [92]. It is evident that students are aware of this, as empathy has no influence on their willingness to implement service robots.

The present study contributes to the literature in several ways: This study is the first to evaluate the attitudes of students of hospitality and tourism (future professionals in that sector) towards the implementation of service robots, providing an explorative insight. Since future implementation of service robots partly depends on younger generations (future managers and experts in the field), it is crucial to reveal their attitudes towards robotization appropriately. Secondly, the existing literature related to technology adoption and the willingness to implement service robots in hospitality and tourism, mainly focuses on customers and their perceptions. On the other hand, attitudes of managers (or future professionals in this case) in that regard are barely examined. Hence, this study expands theoretical insights and largely contributes to the literature. Thirdly, no study has, to the authors' knowledge, examined the influence of expected business outcomes on the decision-makers' willingness to implement service robots. Furthermore, the study identified the most influencing factors related to the students' willingness to implement service robots. The proposed model differs from the others in terms of the new constructs and their content. Having this in mind, the present study should initiate further research and model development regarding implementation of service robots in the hospitality and tourism industry. Conclusively, the present study advances the notion of willingness to implement 
service robots in the hospitality and tourism sector by incorporating new constructs and items in the proposed model.

Based on the study findings, few conclusions can be drawn. It is evident that numerous factors influence the willingness to implement service robots in the hospitality and tourism sectors. However, the expected business outcome seems to be the most important factor among students, followed by the robots' performance and user experience they should provide. These findings should help companies that produce service robots to precisely shape their products for these sectors. More importantly, it should be pointed out that students do not have a strong will to implement service robots, i.e., they have an indefinite attitude in that regard. It indicates a fact that students doubt service robots can substitute human employees (also concluded by [93]), or the fact that they cannot perform complex tasks [94]. As the majority of students do not have an opportunity to personally work with service robots, human service remains the first association to these contact-intensive sectors. Having this in mind, robot producers may need to better promote their products and thoroughly explain all the advantages of service robots implementation, as adequate analysis and planning are crucial for new technology development and implementation [95]. They should reach future professionals while they are still at faculties and gradually prepare them for what seems to be an unavoidable business environment. Organized trainings, trial use, seminars or workshops may contribute to a better understanding and establishment of the robot producer-service provider-customer relationship. Without that approach, and with such knowledge-based and realistic attitudes of future professionals, the implementation of service robots within the hospitality and tourism industry will probably remain sporadic and limited to less contact-intensive settings.

Regarding study limitations, it is worth mentioning that data was collected only at one faculty and in one country (Serbia). The sample size was large enough to perform statistical analyses but it still remains relatively low to draw globally applicable conclusions. Thus, it would be necessary to conduct similar and larger research in other countries as results may vary across cultures [13].

Another factor that may have affected students' willingness to implement service robots, especially the tangibles construct is the lockdown due to the COVID-19 pandemic. The results were acquired during the global pandemic outbreak, which possibly affected the responses. Lastly, future research should focus more on managers' (decision makers') and employees' attitudes and experiences as they are the unavoidable link in the implementation of service robots in these industries.

Author Contributions: Conceptualization, M.I. and I.B.; methodology, I.B. and M.I.; software, G.P.B.; validation, G.P.B., and Z.D.; formal analysis, I.B.; investigation, Z.D.; resources, G.P.B. and B.D.; data duration, Z.D.; writing—original draft preparation, M.I. and I.B.; writing—review and editing, G.P.B. and Z.D.; visualization, B.D.; supervision, B.D.; project administration, B.D.; funding acquisition, Z.D. All authors have read and agreed to the published version of the manuscript.

Funding: This research received no external funding.

Conflicts of Interest: The authors declare no conflict of interest.

\section{References}

1. Belk, R. Consumers in An Age of Autonomous and Semi-autonomous Machines. In Contemporary Consumer Culture Theory, 1st ed.; Sherry, J.F., Fischer, E.M., Eds.; Routledge: New York, NY, USA, 2017; pp. 5-32. ISBN 9781315563947.

2. He, Z.; Wu, L.; Li, X.R. When art meets tech: The role of augmented reality in enhancing museum experiences and purchase intentions. Tour. Manag. 2018, 68, 127-139. [CrossRef]

3. Lu, L.; Cai, R.; Gursoy, D. Developing and validating a service robot integration willingness scale. Int. J. Hosp. Manag. 2019, 80, 36-51. [CrossRef]

4. Murphy, J.; Hofacker, C.; Gretzel, U. Dawning of the age of robots in hospitality and tourism: Challenges for teaching and research. Eur. J. Tour. Res. 2017, 15, 104-111. 
5. Ivanov, S.; Webster, C.; Berezina, K. Adoption of robots and service automation by tourism and hospitality companies. In Proceedings of the INVTUR International Conference, Aveiro, Portugal, 17-19 May 2017; pp. 1501-1517.

6. Bellini, N.; Convert, L. The concierge. Tradition, obsolescence and innovation in tourism. Symph. Emerg. Issues Manag. 2016, 2, 17-25. [CrossRef]

7. Tavakoli, R.; Mura, P. Netnography in tourism-Beyond Web 2.0. Ann. Tour. Res. 2018, 73, 190-192. [CrossRef]

8. Introducing Connie, Hilton's New Robot Concierge. Available online: https://www.usatoday.com/ story/travel/roadwarriorvoices/2016/03/09/introducing-connie-hiltons-new-robot-concierge/81525924/ (accessed on 27 January 2020).

9. Starwood Inter Starwood Introduces Robotic Butlers at Aloft Hotel in Cupertino. Available online: https: //techcrunch.com/2014/08/13/starwood-introducesrobotic-butlers-at-aloft-hotel-in-palo-alto/ (accessed on 18 February 2020).

10. Meet Wally. The Room Service Robot of the Residence Inn Marriott at LAX. Available online: https:// www.foxla.com/news/meet-wally-the-room-service-robot-of-the-residence-inn-marriott-at-lax (accessed on 16 January 2020).

11. Quantum of the Seas: World's' Smartest Cruise Ship' with Robot Waiters and Skydiving. Available online: https://www.cnn.com/2015/03/09/sailing/quantum-of-seas-smartest-cruise-ship/index.html (accessed on 11 February 2020).

12. Inside Japan's First Robot-Stuffed Hotel. Available online: https://www.theguardian.com/travel/2015/aug/14/ japan-henn-na-hotel-staffed-by-robots (accessed on 26 August 2020).

13. Travellers Expect Robots on Their Holidays by 2020. Available online: http://ir.travelzoo.com/static-files/ 3a5005a3-389c-4f2f-a7dd-bd297777024e (accessed on 18 February 2020).

14. Choi, S.; Liu, S.Q.; Mattila, A.S. "How may I help you?" Says a robot: Examining language styles in the service encounter. Int. J. Hosp. Manag. 2019, 82, 32-38. [CrossRef]

15. Duan, Y.; Edwards, J.S.; Dwivedi, Y.K. Artificial intelligence for decision making in the era of Big Data-evolution, challenges and research agenda. Int. J. Inf. Manag. 2019, 48, 63-71. [CrossRef]

16. Wirtz, J.; Patterson, P.G.; Kunz, W.H.; Gruber, T.; Lu, V.N.; Paluch, S.; Martins, A. Brave new world: Service robots in the frontline. J. Serv. Manag. 2018, 29. [CrossRef]

17. van Doorn, J.; Mende, M.; Noble, S.M.; Hulland, J.; Ostrom, A.L.; Grewal, D.; Petersen, A. Domo arigato Mr. Roboto: Emergence of automated social presence in organizational frontlines and customers' service experiences. J. Serv. Res. 2017, 20, 43-58. [CrossRef]

18. Kuo, C.M.; Chen, L.C.; Tseng, C.Y. Investigating an innovative service with hospitality robots. Int. J. Contemp. Hosp. Manag. 2017, 29, 1305-1321. [CrossRef]

19. Tung, V.W.S.; Law, R. The potential for tourism and hospitality experience research in human-robot interactions. Int. J. Contemp. Hosp. Manag. 2017, 29, 2498-2513. [CrossRef]

20. Bolton, R.N.; McColl-Kennedy, J.R.; Cheung, L.; Gallan, A.S.; Orsingher, C.; Witell, L.; Zaki, M. Customer experience challenges: Bringing together digital, physical and social realms. J. Serv. Manag. 2018, 29, 776-808. [CrossRef]

21. Wu, Y.H.; Wrobel, J.; Cornuet, M.; Kerhervé, H.; Damnée, S.; Rigaud, A.S. Acceptance of an assistive robot in older adults: A mixed-method study of human-robot interaction over a 1-month period in the living lab setting. Clin. Interv. Aging 2014, 9, 801-811. [CrossRef] [PubMed]

22. De Kervenoael, R.; Hasan, R.; Schwob, A.; Goh, E. Leveraging human-robot interaction in hospitality services: Incorporating the role of perceived value, empathy, and information sharing into visitors' intentions to use social robots. Tour. Manag. 2020, 78, 104042. [CrossRef]

23. Birnbaum, G.E.; Mizrahi, M.; Hoffman, G.; Reis, H.T.; Finkel, E.J.; Sass, O. What robots 715 can teach us about intimacy: The reassuring effects of robot responsiveness to human disclosure. Comput. Hum. Behav. 2016, 63, 416-423. [CrossRef]

24. Gursoy, D.; Chi, O.H.; Lu, L.; Nunkoo, R. Consumers acceptance of artificially intelligent (AI) device use in service delivery. Internat. J. Inf. Manag. 2019, 49, 157-169. [CrossRef]

25. Tussyadiah, I. A review of research into automation in tourism: Launching the Annals of Tourism Research Curated Collection on Artificial Intelligence and Robotics in Tourism. Ann. Tour. Res. 2020, 81, 102883. [CrossRef] 
26. Ryan, P.; Horton-Tognazzini, L.; Williams, A. A snapshot of MOOCs in hospitality and tourism. J. Hosp.Tour. Educ. 2016, 28, 107-112. [CrossRef]

27. Bartneck, C.; Forlizzi, J. A Design-Centred Framework for Social Human-Robot Interaction. In Proceedings of the Ro-Man 2004 13th IEEE International Workshop on Robot and Human Interactive Communication, Kurashiki, Japan, 20-22 September 2004; pp. 591-594. [CrossRef]

28. Huang, M.H.; Rust, R.T. Artificial intelligence in service. J. Serv. Res. 2018, 21, 155-172. [CrossRef]

29. Dogan, S.; Vatan, A. Hotel Managers' Thoughts towards New Technologies and Service Robots' at Hotels: A Qualitative Study in Turkey. In Advances in Global Business and Economics; Cobanoglu, C., Cavusoglu, M., Corbaci, A., Eds.; ANAHEI Publishing, LLC: Sarasota, FL, USA, 2019; Volume 2, pp. 382-399. ISBN 978-1-7321275-5-5.

30. Hotel Managers' Perceptions towards the Use of Robots: A Mixed-Methods Approach. Available online: File://C:/Users/user/Downloads/Robots-Bulgarianhoteliers-PREPRINT.pdf (accessed on 14 July 2020).

31. Davis, F.D. Perceived usefulness, perceived ease of use, and user acceptance of information technology. Manag. Inf. Syst. Q. 1989, 13, 319-340. [CrossRef]

32. Venkatesh, V.; Morris, M.G.; Davis, G.B.; Davis, F.D. User acceptance of information technology: Toward a unified view. Manag. Inf. Syst. Q. 2003, 27, 425-478. [CrossRef]

33. Venkatesh, V.; Thong, J.Y.; Xu, X. Consumer acceptance and use of information technology: Extending the unified theory of acceptance and use of technology. Manag. Inf. Syst. Q. 2012, 36, 157-178. [CrossRef]

34. Stock, R.; Merkle, M. A service Robot Acceptance Model: User acceptance of humanoid robots during service encounters. In Proceedings of the 2017 IEEE International Conference on Pervasive Computing and Communications Workshops (PerCom Workshops), Kona, HI, USA, 13-17 March 2017; Institute of Electrical and Electronics Engineers: Piscataway, NJ, USA, 2017; pp. 339-344.

35. Lin, H.; Chi, O.H.; Gursoy, D. Antecedents of customers' acceptance of artificially intelligent robotic device use in hospitality services. J. Hosp. Market. Manag. 2019, 1-20. [CrossRef]

36. Cronan, T.P.; Mullins, J.K.; Douglas, D.E. Further understanding factors that explain freshman business students' academic integrity intention and behavior: Plagiarism and sharing homework. J. Bus. Ethics 2018, 147, 197-220. [CrossRef]

37. Fishbein, M.; Ajzen, I. Belief, Attitude, Intention and Behavior: An Introduction to Theory and Research; Addison-Wesley: Boston, MA, USA, 1975.

38. Davis, F.D.; Bogozzi, R.P.; Warshaw, P.R. User acceptance of computer technology:A comparison of two theoretical models. Manag. Sci. 1989, 35, 982-1003. [CrossRef]

39. Han, H.; Hwang, J.; Kim, J.; Jung, H. Guests' pro-environmental decision-making process: Broadening the norm activation framework in a lodging context. Int. J. Hosp. Manag. 2015, 47, 96-107. [CrossRef]

40. Lee, M.; Han, H.; Willson, G. The role of expected outcomes in the formation of behavioral intentions in the green-hotel industry. J. Travel Tour. Mark. 2011, 28, 840-855. [CrossRef]

41. Han, H.; Hsu, L.; Sheu, C. Application of the theory of planned behavior to green hotel choice: Testing the effect of environmentally friendly activities. Tour. Manag. 2010, 31, 325-334. [CrossRef]

42. Pinillos, R.; Marcos, S.; Feliz, R.; Zalama, E.; Gómez-García-Bermejo, J. Long-term assessment of a service robot in a hotel environment. Robot. Auton. Syst. 2016, 79, 40-57. [CrossRef]

43. Ivanov, S.; Webster, C.; Garenko, A. Young Russian adults' attitudes towards the potential use of robots in hotels. Technol. Soc. 2018, 55, 24-32. [CrossRef]

44. Rather, R.A. Investigating the impact of customer brand identification on hospitality brand loyalty: A social identity perspective. J. Hosp. Mark. Manag. 2018, 27, 487-513. [CrossRef]

45. Gursoy, D.; Del Chiappa, G.; Zhang, Y. Impact of destination familiarity on external information source selection process. J. Destin. Mark. Manag. 2018, 8, 137-146. [CrossRef]

46. Venkatesh, V.; Morris, M.G.; Ackerman, P.L. A Longitudinal Field Investigation of Gender Differences in Individual Technology Adoption Decision Making Processes. Organ. Behav. Hum. Dec. 2000, 83, 33-60. [CrossRef] [PubMed]

47. Chakrabarty, S.; Brown, G.; Widing, R.E. The role of top management in developing a customer-oriented sales force. J. Pers. Sell. Sales Manag. 2012, 32, 437-450. [CrossRef]

48. Hwang, K.; Kim, H. Are ethical consumers happy? Effects of ethical consumers' motivations based on empathy versus self-orientation on their happiness. J. Bus. Ethics 2018, 151, 579-598. [CrossRef] 
49. Wieseke, J.; Geigenmüller, A.; Kraus, F. On the role of empathy in customer-employee interactions. J. Serv. Res. 2012, 15, 316-331. [CrossRef]

50. Parasuraman, A.; Zeithaml, V.A.; Berry, L.L. SERVQUAL: A multiple-item scale for measuring consumer perceptions of service quality. J. Retail. 1988, 64, 12-40.

51. Kim, S.S.; Malhotra, N.K. A Longitudinal Model of Continued IS Use: An Integrative View of Four Mechanisms Underlying Post-Adoption Phenomena. Manag. Sci. 2005, 51, 741-755. [CrossRef]

52. Brown, S.A.; Venkatesh, V. Model of Adoption of Technology in the Household: A Baseline Model Test and Extension Incorporating Household Life Cycle. Manag. Inf. Syst. Q. 2005, 29, 399-426. [CrossRef]

53. Van der Heijden, H. User Acceptance of Hedonic Infor- mation Systems. Manag. Inf. Syst. Q. 2004, 28, 695-704. [CrossRef]

54. Allam, H.; Bliemel, M.; Spiteri, L.; Blustein, J.; Ali-Hassan, H. Applying a multidimensional hedonic concept of intrinsic motivation on social tagging tools: A theoretical model and empirical validation. Int. J. Inf. Manag. 2019, 45, 211-222. [CrossRef]

55. Law, R.; Chan, I.C.C.; Wang, L. A comprehensive review of mobile technology use in hospitality and tourism. J. Hosp. Market. Manag. 2018, 27, 626-648. [CrossRef]

56. Zeithaml, V.A.; Parasuraman, A.; Berry, L.L.; Berry, L.L. Delivering Quality Service: Balancing Customer Perceptions and Expectations; The Free Press: New York, NY, USA, 1990; pp. 1-219. ISBN 0-02-935701-2.

57. Morita, T.; Kashiwagi, N.; Yorozu, A.; Suzuki, H.; Yamaguchi, T. Evaluation of a Multi-robot Cafe Based on Service Quality Dimensions. Rev. Socionetwork Strateg. 2020, 14, 55-76. [CrossRef]

58. Impacts of Service Robots on Service Quality. Available online: https://journals.aom.org/doi/abs/10.5465/ AMBPP.2019.15905abstract (accessed on 18 January 2020).

59. McKnight, D.H.; Carter, M.; Thatcher, J.B.; Clay, P.F. Trust in a specific technology: An investigation of its components and measures. ACM Trans. Manag. Inf. Syst. 2011, 2, 12-32. [CrossRef]

60. Park, S. Multifaceted trust in tourism service robots. Ann. Tour. Res. 2020, 81, 102888. [CrossRef]

61. Um, T.; Kim, T.; Chung, N. How does an Intelligence Chatbot Affect Customers Compared with Self-Service Technology for Sustainable Services? Sustainability 2020, 12, 5119. [CrossRef]

62. Nair, G. Impact of Service quality on business performance in hospitality industries: An empirical study. J. Tour. Hosp. Sports 2016, 17, 2312-5817. [CrossRef]

63. Kaiser, H.F. An index of factorial simplicity. Psychometrika 1974, 39, 31-36. [CrossRef]

64. Bartlett, M.S. A Note on the Multiplying Factors for Various Chi Square Approximations. J. Royal Stat. Soc. 1954, 16, 296-298. [CrossRef]

65. Tabachnick, B.G.; Fidell, L.S. Using Multivariate Statistics, 5th ed.; Allyn \& Bacon/Pearson Education: Boston, MA, USA, 2007.

66. Nunnally, J.C. Psychometric Theory, 2nd ed.; McGraw-Hill: New York, NY, USA, 1978; pp. 1-701. ISBN 13 978-0070474659.

67. Muthén, L.K.; Muthén, B.O. Mplus User's Guide, 7th ed.; Muthen \& Muthen: Los Angeles, CA, USA, 2012; pp. 1-805.

68. Bentler, P.M. Comparative fit indexes in structural models. Psychol. Bull. 1990, 107, 238-246. [CrossRef]

69. Hu, L.T.; Bentler, P.M. Cutoff criteria for fit indexes in covariance structure analysis: Conventional criteria versus new alternatives. Struct. Equ. Modeling 1999, 6, 1-55. [CrossRef]

70. Kelloway, E.K. Using Mplus for Structural Equation Modeling: A Researcher's Guide, 2nd ed.; Sage Publications: Los Angeles, CA, USA, 2015; pp. 1-250. ISBN 978-1-4522-9147-5.

71. Hair, J.F., Jr.; Hult, G.T.M.; Ringle, C.; Sarstedt, M. A Primer on Partial Least Squares Structural Equation Modeling (PLS-SEM); Sage Publications: Thousand Oaks, CA, USA, 2016; pp. 1-390.

72. Fornell, C.; Larcker, D.F. Evaluating structural equation models with unobservable variables and measurement error. J. Mark. Res. 1981, 18, 39-50. [CrossRef]

73. Hair, J.; Black, W.; Babin, B.; Anderson, R. Multivariate Data Analysis, 7th ed.; Prentice-Hall: Bergen County, NJ, USA, 2010; pp. 1-761.

74. Kaczor, S.; Kryvinska, N. It is all about services-fundamentals, drivers, and business models. J. Serv. Sci. Res. 2013, 5, 125-154. [CrossRef]

75. Molnár, E.; Molnár, R.; Kryvinska, N.; Greguš, M. Web intelligence in practice. J. Serv. Sci. Res. 2014, 6, 149-172. [CrossRef] 
76. Ivanov, S.; Webster, C. Designing robot-friendly hospitality facilities. In Proceedings of the Scientific Conference “Tourism. Innovations. Strategies", Bourgas, Bulgaria, 13-14 October 2017; pp. 74-81.

77. Radde, B. Digital Guest Experience: Tools to Help Hotels to Manage and Optimize The Digital Guest Experience, 1st ed.; Tredition GmbH: Hamburg, Germany, 2017; pp. 1-152. ISBN 978-3-7323-9338-1.

78. Huang, J.Y.; Lee, W.P.; Chen, C.C.; Dong, B.W. Developing Emotion-Aware Human-Robot Dialogues for Domain-Specific and Goal-Oriented Tasks. Robotics 2020, 9, 31. [CrossRef]

79. Chau, P.Y.K.; Hui, K.L. Identifying Early Adopters of New IT Products: A Case of Windows 95. Inf. Manag. 1998, 33, 225-230. [CrossRef]

80. Seyitoğlu, F.; Ivanov, S. Service robots as a tool for physical distancing in tourism. Curr. Issues Tour. 2020. In Press. [CrossRef]

81. Gremler, D.D.; Gwinner, K.P. Rapport-building behaviors used by retail employees. J. Retail. 2008, 84, 308-324. [CrossRef]

82. Petrović, J.; Milićević, S.; Đeri, L. The information and communication technology as a factor of destination competitiveness in transition countries in European Union. Tour. Econ. 2017, 23, 1353-1361. [CrossRef]

83. Bontis, N.; Richards, D.; Serenko, A. Improving service delivery: Investigating the role of information sharing, job characteristics, and employee satisfaction. Learn. Organ. 2011, 18. [CrossRef]

84. Vandermerwe, S. Achieving deep customer focus. IEEE Eng. Manag. Rev. 2004, 45, 62. [CrossRef]

85. Tung, V.W.S.; Au, N. Exploring customer experiences with robotics in hospitality. Int. J. Contemp. Hosp. Manag. 2018, 30, 2680-2697. [CrossRef]

86. Venkatesh, V.; Davis, F.D. A Theoretical Extension of the Technology Acceptance Model: Four Longitudinal Field Studies. Manag. Sci. 2000, 45, 186-204. [CrossRef]

87. Venkatesh, V.; Morris, M.G. Why Don't Men Ever Stop to Ask For Directions? Gender, Social Influence, and Their Role in Technology Acceptance and Usage Behavior. Manag. Inf. Syst. Q. 2000, 24, 115-139. [CrossRef]

88. Study: Nobody Wants Social Robots That Look Like Humans Because They Threaten Our Identity. Available online: https://spectrum.ieee.org/automaton/robotics/humanoids/study-nobody-wants-social-robots-thatlook-like-humans (accessed on 27 January 2020).

89. Zhang, C.; Li, Y.; Wu, B.; Li, D. How WeChat can retain users: Roles of network externalities, social interaction ties, and perceived values in building continuance intention. Comput. Hum. Behav. 2017, 69, $284-293$. [CrossRef]

90. Fryer, L.K.; Ainley, M.; Thompson, A.; Gibson, A.; Sherlock, Z. Stimulating and sustaining interest in a language course: An experimental comparison of Chatbot and Human task partners. Comput. Hum. Behav. 2017, 75, 461-468. [CrossRef]

91. Leite, I.; Pereira, A.; Mascarenhas, S.; Martinho, C.; Prada, R.; Paiva, A. The influence of empathy in human-robot relations. Int. J. Hum. Comput. Stud. 2013, 71, 250-260. [CrossRef]

92. Manyika, J.; Chui, M.; Bughin, J.; Dobbs, R.; Bisson, P.; Marrs, A. Disruptive Technologies: Advances that Will Transform Life, Business, and the Global Economy; McKinsey Global Institute: San Francisco, CA, USA, 2013; pp. 1-176.

93. Qiu, H.; Li, M.; Shu, B.; Bai, B. Enhancing hospitality experience with service robots: The mediating role of rapport building. J. Hosp. Market. Manag. 2020, 29, 247-268. [CrossRef]

94. Lee, W.J.; Kwag, S.I.; Ko, Y.D. Optimal capacity and operation design of a robot logistics system for the hotel industry. Tour. Manag. 2020, 76, 103971. [CrossRef]

95. Kryvinska, N. Building consistent formal specification for the service enterprise agility foundation. J. Serv. Sci. Res. 2012, 4, 235-269. [CrossRef]

(C) 2020 by the authors. Licensee MDPI, Basel, Switzerland. This article is an open access article distributed under the terms and conditions of the Creative Commons Attribution (CC BY) license (http://creativecommons.org/licenses/by/4.0/). 